Article

\title{
Highly Sensitive and Selective Colorimetric Detection of Methylmercury Based on DNA Functionalized Gold Nanoparticles
}

\author{
Zheng-Jun Xie ${ }^{1,2}$, Xian-Yu Bao ${ }^{2,3}$ and Chi-Fang Peng ${ }^{1,2, *(D)}$ \\ 1 State Key Laboratory of Dairy Biotechnology, Shanghai Engineering Research Center of Dairy Biotechnology, \\ Dairy Research Institute, Bright Dairy \& Food Co., Ltd., Shanghai 200436, China; xiezj@jiangnan.edu.cn \\ 2 School of Food Science and Technology, Jiangnan University, Wuxi 214122, China; \\ 6150111037@vip.jiangnan.edu.cn \\ 3 Shenzhen Academy of Inspection and Quarantine, Shenzhen 518045, China \\ * Correspondence: pcf@jiangnan.edu.cn; Tel.: +86-510-8591-9189
}

Received: 11 June 2018; Accepted: 30 July 2018; Published: 15 August 2018

check for updates

\begin{abstract}
A new colorimetric detection of methylmercury $\left(\mathrm{CH}_{3} \mathrm{Hg}^{+}\right)$was developed, which was based on the surface deposition of $\mathrm{Hg}$ enhancing the catalytic activity of gold nanoparticles (AuNPs). The AuNPs were functionalized with a specific DNA strand $\left(\mathrm{H}_{\mathrm{T} 7}\right)$ recognizing $\mathrm{CH}_{3} \mathrm{Hg}^{+}$, which was used to capture and separate $\mathrm{CH}_{3} \mathrm{Hg}^{+}$by centrifugation. It was found that the $\mathrm{CH}_{3} \mathrm{Hg}^{+}$reduction resulted in the deposition of $\mathrm{Hg}$ onto the surface of AuNPs. As a result, the catalytic activity of the AuNPs toward the chromogenic reaction of 3,3,5,5-tetramethylbenzidine (TMB) $-\mathrm{H}_{2} \mathrm{O}_{2}$ was remarkably enhanced. Under optimal conditions, a limit of detection of $5.0 \mathrm{nM}$ was obtained for $\mathrm{CH}_{3} \mathrm{Hg}^{+}$with a linear range of 10-200 nM. We demonstrated that the colorimetric method was fairly simple with a low cost and can be conveniently applied to $\mathrm{CH}_{3} \mathrm{Hg}^{+}$detection in environmental samples.
\end{abstract}

Keywords: methylmercury; gold nanoparticles; enzyme mimic; chromogenic reaction

\section{Introduction}

Mercuric ions widely exist in the environment and have distinct toxic effects on human beings. Organic forms of mercury $(\mathrm{Hg})$ demonstrate much higher toxicity than inorganic $\mathrm{Hg}$ due to their higher lipophilicity and easier bioaccumulation through the food chain, such as in the tissue of fish [1,2]. The main organic species of mercury, methylmercury $\left(\mathrm{CH}_{3} \mathrm{Hg}^{+}\right)$, has been recognized as a potent neurotoxin that causes damage to the brain and nervous system [1,3]. Due to the severe effects of mercury, the U.S. Environmental Protection Agency has set a maximum level (10 nM, $2 \mathrm{ppb})$ for mercury species in drinking water [1]. Usually, complex hyphenated techniques, such as high performance liquid chromatography (HPLC) or gas chromatography (GC), coupled to specific detectors, such as mass spectrometry (MS), inductively coupled plasma mass spectrometry (ICP-MS) or atomic fluorescence spectrometry (AFS), are required for methylmercury detection [4-6]. However, these techniques generally require expensive instruments and are time-consuming and costly. To overcome the limitation of the above methods, recently, nanomaterial-based assays have been widely used for developing rapid and cost-effective methods for the detection of various heavy metal ions in environmental and biological samples [7-9]. Due to the strong metallophilic interactions between $\mathrm{Hg}^{2+}$ and some other metallic atoms, such as gold and silver, numerous metallic nanoparticle-based assays for $\mathrm{Hg}^{2+}$ have been developed [10-16]. However, there are fewer nanomaterial-based assays for $\mathrm{CH}_{3} \mathrm{Hg}^{+}$compared to $\mathrm{Hg}^{2+}$ ions [17-19], which is probably due to the weak interactions between $\mathrm{CH}_{3} \mathrm{Hg}^{+}$and metal nanomaterials. 
Only a few studies have reported the development of nanomaterial-based detection methods for $\mathrm{CH}_{3} \mathrm{Hg}^{+}$. For example, Chen at el. developed a colorimetric nanosensor for mercury speciation, which was based on the analyte-induced aggregation of gold nanoparticles (Au NPs) with the assistance of a thiol-containing ligand of diethyldithiocarbamate (DDTC) [18]. Pandeeswar et al. presented a novel optoelectronic approach for detection of $\mathrm{Hg}^{2+}$ and $\mathrm{CH}_{3} \mathrm{Hg}^{+}$, which was based on nanoarchitectonics that consists of an adenine (A)-conjugated small organic semiconductor (BNA) and deoxyribo-oligothymidine (dTn) [20]. However, this device cannot distinguish $\mathrm{Hg}^{2+}$ from $\mathrm{CH}_{3} \mathrm{Hg}^{+}$. Recently, Deng et al. reported that a DNA strand, $\mathrm{H}_{\mathrm{T} 7}$, can bind to $\mathrm{CH}_{3} \mathrm{Hg}^{+}$with a higher $\mathrm{K}_{\mathrm{b}}$ value of $(5.57 \pm 0.47) \times 10^{6} \mathrm{M}^{-1}$ compared to that of $\mathrm{Hg}^{2+}\left((1.51 \pm 0.18) \times 10^{6} \mathrm{M}^{-1}\right)$ [19]. Based on this, they were able to discriminate between $\mathrm{CH}_{3} \mathrm{Hg}^{+}$and $\mathrm{Hg}^{2+}$ ions by forming $\mathrm{Ag} / \mathrm{Hg}$ amalgam with a $\mathrm{CH}_{3} \mathrm{Hg}^{+}$-specific fluorophore-labeled DNA probe and fabricated a highly selective fluorescent assay for $\mathrm{CH}_{3} \mathrm{Hg}^{+}$. More recently, Yang et al. designed a specific visual detection method for $\mathrm{CH}_{3} \mathrm{Hg}^{+}$and ethylmercury based on DNA-templated alloy Ag/Au NPs [21]. However, this visual detection method for methylmercury and ethylmercury requires subtle temperature adjustments and its sensitivity was above the micromolar level. Thus, developing a simple and selective colorimetric assay for $\mathrm{CH}_{3} \mathrm{Hg}^{+}$is still an important and difficult task.

Recently, some methods for the detection of $\mathrm{Hg}^{2+}$ were reported, which were based on the peroxidase-like activity of the AuHg alloy NPs. For example, Long et al. [22] found that AuNPs possess excellent peroxidase-like activity after the deposition of $\mathrm{Hg}^{2+}$ onto the surface of AuNPs. The peroxidase-like activity enhancement of AuNPs, after $\mathrm{Hg}^{0}$ deposition onto the surface of AuNPs, was suggested to be the result of the accelerated decomposition of $\mathrm{H}_{2} \mathrm{O}_{2}$ and the stabilization of hydroxyl radicals on the surface of AuNPs. This phenomenon can be applied in the development of colorimetric and fluorescent assays for $\mathrm{Hg}^{2+}$ [22-24]. Our group also reported that catalytic DNA-AuNPs and DNA-Ag/Pt nanoclusters can be used to detect $\mathrm{Hg}^{2+}$ with high selectivity and sensitivity by stimulating or inhibiting their peroxidase-like activity $[25,26]$. Interestingly, compared with citrate stabilized AuNPs, AuNPs functionalized with a T-rich DNA strand can obviously improve the selectivity and can simplify the sample pretreatment for the colorimetric detection of $\mathrm{Hg}^{2+}$ [25]. However, to the best of our knowledge, there is no report on the application of nanomaterial enzyme mimics in $\mathrm{CH}_{3} \mathrm{Hg}^{+}$detection. Herein, we found that $\mathrm{CH}_{3} \mathrm{Hg}^{+}$captured by the AuNPs functionalized with $\mathrm{CH}_{3} \mathrm{Hg}^{+}$-specific DNA strands can be reduced by $\mathrm{NaBH}_{4}$. This results in $\mathrm{Hg}$ deposition onto the surface of AuNPs, thus stimulating the peroxidase-like activity of the AuNPs. Based on this finding, a highly sensitive and selective colorimetric assay for $\mathrm{CH}_{3} \mathrm{Hg}^{+}$was developed.

\section{Materials and Methods}

\subsection{Chemicals and Materials}

$\mathrm{HAuCl}_{4}, \mathrm{CH}_{3} \mathrm{Hg}^{+} \mathrm{Cl}, \mathrm{NaBH}_{4}, 3,3,5,5-$ Tetramethylbenzidine (TMB) and $\mathrm{H}_{2} \mathrm{O}_{2}(30 \%$ ) were purchased from Aladdin Reagent (Shanghai, China). The single-strand oligonucleotides were obtained from Sangon Biotech (Shanghai, China) and the sequences of these DNA strands were listed in Table 1. $\mathrm{Hg}\left(\mathrm{NO}_{3}\right)_{2}$ and all the other metal salts were purchased from the National Institute of Metrology (Beijing, China). All of the reagents used were of analytical grade. Ultra-pure water prepared with a Milli-Q Pure system was used for all experiments. 
Table 1. Oligonucleotide Sequences Used in This Work ${ }^{\text {a }}$.

\begin{tabular}{cc}
\hline Type & \multicolumn{1}{c}{ Sequence } \\
\hline $\mathrm{H}_{\mathrm{T} 5}$ & $5^{\prime}$-SH-CTTTGTTAAAAATTCTTTG-3' \\
$\mathrm{H}_{\mathrm{T} 7}$ & $5^{\prime}$-SH-GTTCTTTGTTAAAAATTCTTTGTTC-3' \\
$\mathrm{H}_{\mathrm{T} 9}$ & $5^{\prime}$-SH-TTGTTCTTTGTTAAAAATTCTTTGTTCTT-3' \\
$\mathrm{H}_{\mathrm{R}}$ & $5^{\prime}$-SH-CTGCTGCTGCAAAAAGCAGCAGCAG-3' \\
\hline
\end{tabular}

${ }^{\text {a }} \mathrm{H}_{\mathrm{T} 5}, \mathrm{H}_{\mathrm{T} 7}$ and $\mathrm{H}_{\mathrm{T} 9}$ represent $\mathrm{CH}_{3} \mathrm{Hg}^{+}$-specific DNA with different $\mathrm{T}$ bases, while $\mathrm{H}_{\mathrm{R}}$ represents random DNA.

\subsection{Synthesis of AuNPs and the Modification by DNA Strands}

The AuNPs were prepared through the citrate-mediated reduction of $\mathrm{HAuCl}_{4}$ [24]. Briefly, $\mathrm{HAuCl}_{4}(0.01 \%, 100 \mathrm{~mL})$ was added to a flask, which had been washed with aqua regia and ultra-pure water. After the solution was heated to boiling, sodium citrate $(1.0 \%, 2.0 \mathrm{~mL})$ was quickly added with stirring. When we observed a color change in the mixture to wine red, the mixture was further boiled for another $5 \mathrm{~min}$ and cooled to room temperature. The diameter of AuNPs was about $15 \mathrm{nM}$ and their concentration was estimated to be $3 \mathrm{nM}$.

The DNA modification of the AuNPs was achieved by directly incubating thiolated single-strand DNA $\left(\mathrm{H}_{\mathrm{T} 7}\right)$ with the AuNPs. Briefly, the AuNPs $(3 \mathrm{nM}, 990 \mu \mathrm{L})$ and thiolated DNA $(100 \mu \mathrm{M}, 5 \mu \mathrm{L})$ were mixed together and incubated at an ambient temperature for $24 \mathrm{~h}$. After this, the mixture was centrifuged for $15 \mathrm{~min}$ at $10,000 \times \mathrm{g}$ rpm and excessive DNA strands were removed. After repeating the centrifugation once, the obtained DNA-AuNPs complex was resuspended in phosphate buffer (10 mM, pH of 7.0) and stored at $4{ }^{\circ} \mathrm{C}$.

\subsection{Colorimetric Detection of $\mathrm{CH}_{3} \mathrm{Hg}^{+}$}

To $25 \mu \mathrm{L}$ of DNA-AuNPs complex $(0.6 \mathrm{nM}), 175 \mu \mathrm{L}$ of Tris- $\mathrm{HNO}_{3}$ buffer $(5.0 \mathrm{mM}, \mathrm{pH} 7.0)$ and $500 \mu \mathrm{L}$ of $\mathrm{CH}_{3} \mathrm{Hg}^{+}$solution at different concentrations were added. After being incubated for $10 \mathrm{~min}$, the mixtures were centrifuged at 10,000 rpm for $15 \mathrm{~min}$ and the supernatants were discarded. To the $50 \mu \mathrm{L}$ of retained mixture, we added $50 \mu \mathrm{L}$ of $\mathrm{NaBH}_{4}(1.0 \mathrm{mM})$. After being incubated for another $10 \mathrm{~min}, 90 \mu \mathrm{L}$ of citrate buffer $(100 \mathrm{mM}, \mathrm{pH} 4.5), 100 \mu \mathrm{L}$ of TMB $(1.5 \mathrm{mM})$ and $60 \mu \mathrm{L}$ of $\mathrm{H}_{2} \mathrm{O}_{2}(1.5 \mathrm{M})$ were transferred into the solution. The catalytic reaction was subsequently recorded at $650 \mathrm{~nm}$ by a microplate reader (PowerWave $\mathrm{XS}_{2}$, Bio-Tek, Winooski, VT, USA) after $10 \mathrm{~min}$. For detection of $\mathrm{CH}_{3} \mathrm{Hg}^{+}$in lake water, the samples were filtered through microfiltration membranes and measured by the above method.

\section{Results and Discussion}

\subsection{Characterization of AuNPs and DNA-AuNPs Complex}

Figure 1 shows that the UV-vis absorption spectra of the AuNPs has a maximum absorption peak $\left(\lambda_{\max }\right)$ at $520 \mathrm{~nm}$. After the AuNPs were modified with $\mathrm{H}_{\mathrm{T}}$, which is a $\mathrm{CH}_{3} \mathrm{Hg}^{+}$recognition DNA strand, the $\lambda_{\max }$ of the AuNPs experienced a red shift to $522 \mathrm{~nm}$. This result suggested that the DNA-AuNPs complex ( $\mathrm{H}_{\mathrm{T} 7}$-AuNPs) was obtained. The $\mathrm{H}_{\mathrm{T} 7}$-AuNPs complex was stable in $0.15 \mathrm{M} \mathrm{NaCl}$ (the inset in Figure 1), which also indicated the successful preparation of the $\mathrm{H}_{\mathrm{T} 7}$-AuNPs. 


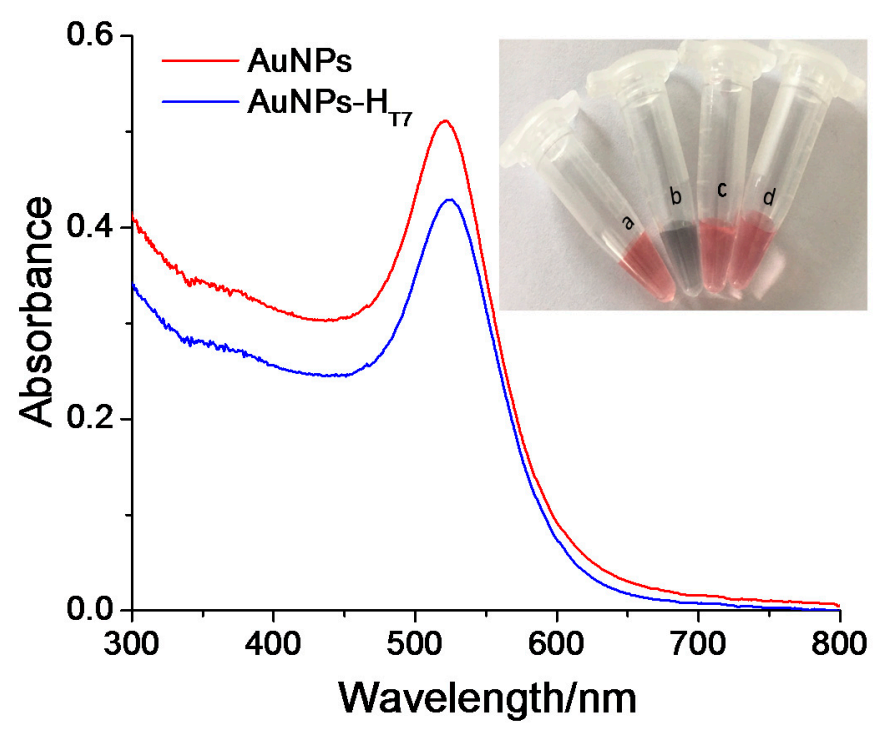

Figure 1. UV-vis spectra of AuNPs and AuNPs-H $\mathrm{H}_{\mathrm{T}}$. The inset shows the photographs of (a) AuNPs, (b) AuNPs with $0.15 \mathrm{~mol} / \mathrm{L} \mathrm{NaCl}$, (c) AuNPs-H $\mathrm{H}_{\mathrm{T}}$ and (d) AuNPs-H $\mathrm{H}_{\mathrm{T}}$ with $0.15 \mathrm{~mol} / \mathrm{L} \mathrm{NaCl}$.

\subsection{Colorimetric Detection of $\mathrm{CH}_{3} \mathrm{Hg}^{+}$}

As shown in Figure 2, AuNPs- $\mathrm{H}_{\mathrm{T} 7}$ demonstrated weak catalytic activity and we only found a weak signal with a peak at $650 \mathrm{~nm}$. After being captured by the $\mathrm{H}_{77}$ strand, $\mathrm{CH}_{3} \mathrm{Hg}^{+}$species can be deposited onto the surface of AuNPs through $\mathrm{Au} / \mathrm{Hg}$ amalgamation since they can be reduced to $\mathrm{Hg}^{0}$ by $\mathrm{NaBH}_{4}[19,27,28]$. In the above process, the catalytic activity of AuNPs-HT $\mathrm{H}_{7}$ was obviously increased, which was supported by the appearance of a strong signal at $650 \mathrm{~nm}$. This was due to the oxidation of TMB by the hydroxyl radical that is stabilized on the surface of AuNPs, which produces a blue one-electron oxidation product (i.e., cation free-radical, $\mathrm{TMB}^{+}$) [29]. The reaction is shown in Figure S1. This change in peroxidase-like activity of the AuNPs suggests the deposition of $\mathrm{Hg}$ onto the surface of AuNPs [22,25]. The $\mathrm{CH}_{3} \mathrm{Hg}^{+}$sensing mechanism is depicted in Scheme 1.

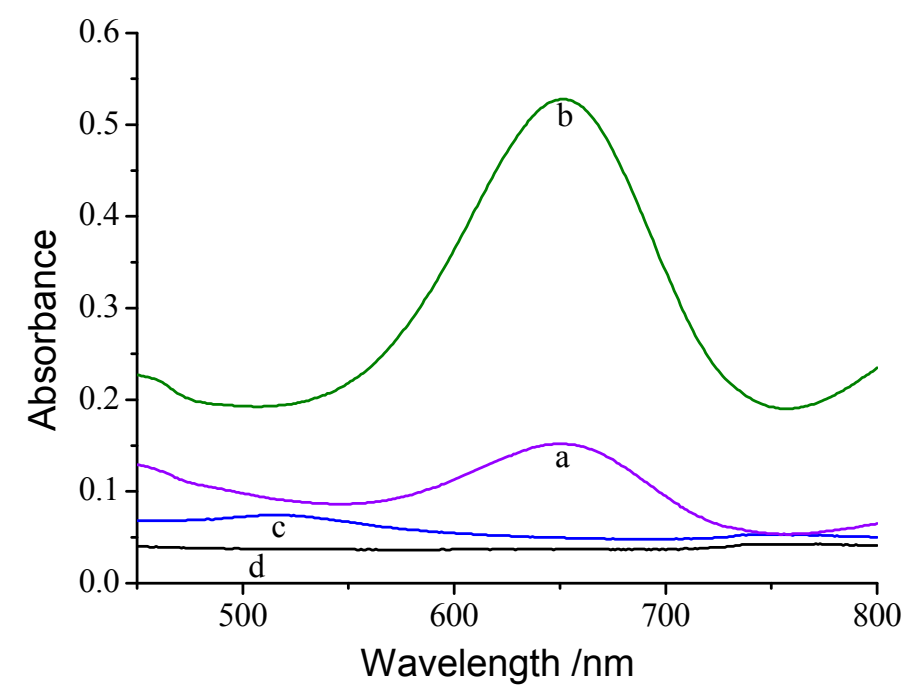

Figure 2. UV-vis spectra of AuNPs- $\mathrm{H}_{\mathrm{T}}+\mathrm{TMB}-\mathrm{H}_{2} \mathrm{O}_{2}$ reaction solution (a) before and (b) after capturing $\mathrm{CH}_{3} \mathrm{Hg}^{+}$and $\mathrm{Hg}$ deposition, (c) AuNPs- $\mathrm{H}_{\mathrm{T} 7}$ solution and (d) $\mathrm{TMB}-\mathrm{H}_{2} \mathrm{O}_{2}$ substrate. 


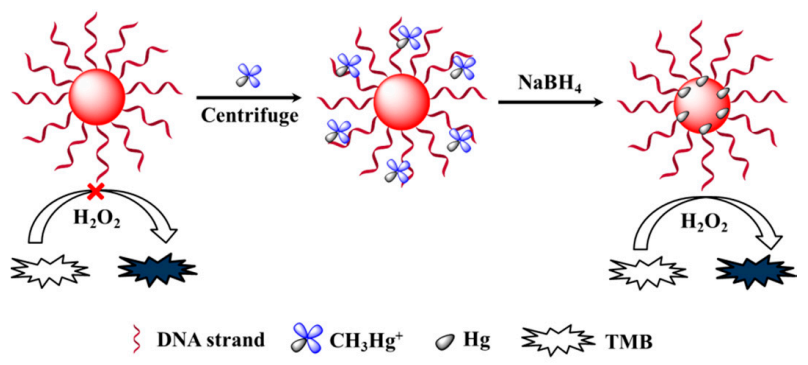

Scheme 1. $\mathrm{CH}_{3} \mathrm{Hg}^{+}$sensing mechanism.

Since the number of T-T pairs may affect the response of the AuNPs-ssDNA complex to $\mathrm{CH}_{3} \mathrm{Hg}^{+}$, $\mathrm{H}_{\mathrm{T} 5}, \mathrm{H}_{\mathrm{T} 7}$ and $\mathrm{H}_{\mathrm{T} 9}$ strands were used to modify the AuNPs, respectively, before we carried out a comparison of these AuNPs-ssDNA complexes. These AuNPs-ssDNA complexes were also characterized by UV-vis spectra, which demonstrated the same change compared with the AuNPs. As shown in Figure 3, $\mathrm{H}_{\mathrm{T} 7}$ modified AuNPs demonstrated more sensitive responses to $\mathrm{CH}_{3} \mathrm{Hg}^{+}$ compared to $\mathrm{H}_{\mathrm{T} 5}, \mathrm{H}_{\mathrm{T} 9}$ or $\mathrm{H}_{\mathrm{R}}$ modified AuNPs. This result suggested that the higher affinity of DNA strand to $\mathrm{CH}_{3} \mathrm{Hg}^{+}$over $\mathrm{Hg}^{2+}$ was still the main factor determining the selectivity of this probe [19].

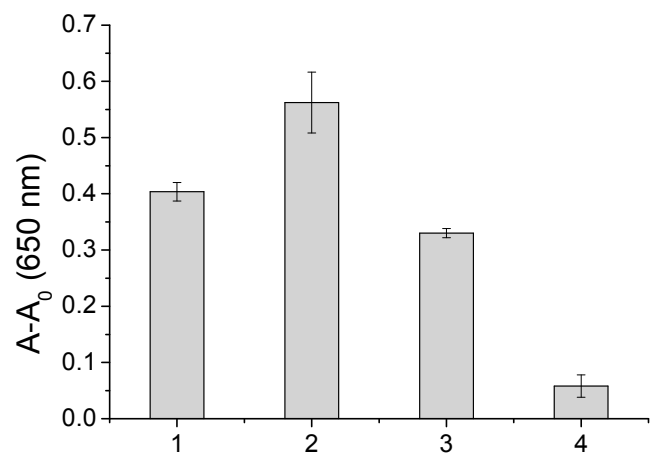

Figure 3. Effect of DNA sequence on the colorimetric detection for $\mathrm{CH}_{3} \mathrm{Hg}^{+}$. AuNPs, $0.6 \mathrm{nM} ; \mathrm{CH}_{3} \mathrm{Hg}^{+}$, $100 \mathrm{nM}$. TMB, $1.0 \times 10^{-3} \mathrm{M} ; \mathrm{H}_{2} \mathrm{O}_{2}, 1.5 \mathrm{M} ; \mathrm{pH}$, 4.5; and incubation time, $25 \mathrm{~min}$.

The enhanced peroxidase-like activity of AuNPs caused by $\mathrm{CH}_{3} \mathrm{Hg}^{+}$was further applied in the development of a colorimetric assay for $\mathrm{CH}_{3} \mathrm{Hg}^{+}$. As shown in Figure 4, the absorbance increased as the $\mathrm{CH}_{3} \mathrm{Hg}^{+}$concentration increased in the range of $0-1000 \mathrm{nM}$. A good linear relationship between $\mathrm{CH}_{3} \mathrm{Hg}^{+}$concentration and absorbance values can be obtained in the range of $10-200 \mathrm{nM}$. The limit of detection (3-fold signal to noise, $\mathrm{S} / \mathrm{N}=3$ ) was evaluated to be $5.0 \mathrm{nM}$.

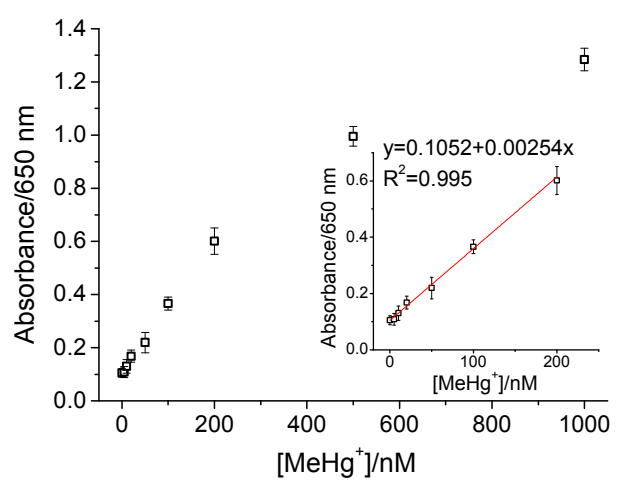

Figure 4. Calibration curve for the detection of $\mathrm{CH}_{3} \mathrm{Hg}^{+}$. AuNPs, $6.0 \times 10^{-10} \mathrm{M}$; TMB, $1.5 \times 10^{-3} \mathrm{M}$; $\mathrm{H}_{2} \mathrm{O}_{2}, 1.5 \mathrm{M} ; \mathrm{Hg}^{2+}, 4.0 \times 10^{-7} \mathrm{M} ; \mathrm{pH}, 4.4$; and incubation time, $20 \mathrm{~min}$. 
Some common metal ions were tested in this colorimetric assay. As shown in Figure 5, most of common metal ions at a 20-fold higher concentration and the same concentration of $\mathrm{Hg}^{2+}$ showed very weak responses. On the contrary, when citrate-stabilized AuNPs were incubated with $\mathrm{Hg}^{2+}$ or $\mathrm{CH}_{3} \mathrm{Hg}^{+}$ions, almost the same catalytic enhancement of AuNPs was observed (Figure S2). The above results clearly demonstrated the good selectivity of this colorimetric assay for $\mathrm{CH}_{3} \mathrm{Hg}^{+}$, which was mainly due to the two aspects: (1) $\mathrm{CH}_{3} \mathrm{Hg}^{+}$-specific DNA scaffold has much higher affinity to $\mathrm{CH}_{3} \mathrm{Hg}^{+}$ $\left(\mathrm{a} K_{\mathrm{b}}\right.$ value of $\left.(5.57 \pm 0.47) \times 10^{6} \mathrm{M}^{-1}\right)$ compared to $\mathrm{Hg}^{2+}\left((1.51 \pm 0.18) \times 10^{6} \mathrm{M}^{-1}\right)$; and (2) the centrifugation and separation of AuNPs- $\mathrm{H}_{\mathrm{T} 7}$ enriched $\mathrm{CH}_{3} \mathrm{Hg}^{+}$over $\mathrm{Hg}^{2+}$. It also should be pointed out that $\mathrm{Hg}^{2+}$ has good affinity with AuNPs. However, the DNA strand on the AuNPs will interact with $\mathrm{Hg}^{2+}$ and thus, will eventually affect the deposition of $\mathrm{Hg}^{0}$. In this case, the $\mathrm{H}_{\mathrm{T} 7}$ strands probably hindered the deposition of $\mathrm{Hg}^{2+}$.

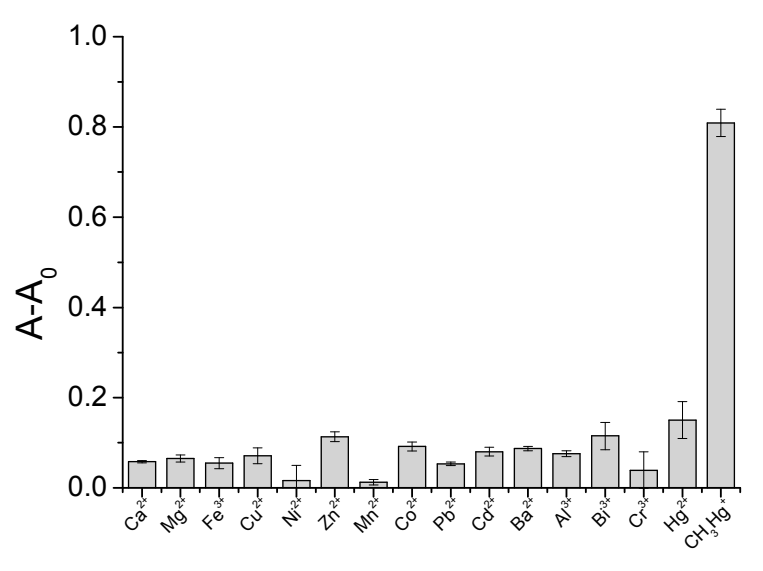

Figure 5. Selectivity of the colorimetric assay for $\mathrm{CH}_{3} \mathrm{Hg}^{+}$.

The sensitivity of the proposed method was higher than the two typical colorimetric methods [18,21] and comparable with some typical nanosensors or chemosensors (Table 2) [1,17,30,31]. However, the selectivity of this method needs to be further improved when compared with the established colorimetric [21] and fluorescent methods [19,30].

The real water samples from the Li Lake in Wuxi, Jiangsu Province were obtained and spiked with different concentrations of $\mathrm{CH}_{3} \mathrm{Hg}^{+}(20 \mathrm{nM}, 50 \mathrm{nM}$ and $100 \mathrm{nM})$. As shown in Table 3, the recovery of the added $\mathrm{CH}_{3} \mathrm{Hg}^{+}$with the colorimetric method was in the range of $93.6-102.1 \%$, which demonstrated the reliability of this assay for the detection of $\mathrm{CH}_{3} \mathrm{Hg}^{+}$in real samples. 
Table 2. Summarize of some typical method of $\mathrm{CH}_{3} \mathrm{Hg}^{+}$.

\begin{tabular}{|c|c|c|c|c|c|c|}
\hline Method & Probe & Limit of Detection & Linear Range & Selectivity to $\mathrm{Hg}^{2+}$ & Sample & Ref. \\
\hline Fluorescent & Lys VI-AuNCs & $\begin{array}{c}\mathrm{CH}_{3} \mathrm{Hg}^{+}: 3 \mathrm{pM} \\
\mathrm{Hg}^{2+}: 4 \mathrm{nM}\end{array}$ & $\begin{array}{c}\mathrm{CH}_{3} \mathrm{Hg}^{+}: 15-500 \mathrm{nM} \\
\mathrm{Hg}^{2+}: 10-5000 \mathrm{pM}\end{array}$ & & seawater & {$[1]$} \\
\hline $\begin{array}{l}\text { Upconversion } \\
\text { fluorescence }\end{array}$ & hCy7-UCNPs & $0.8 \mathrm{ppb}$ & $0-7 \mu \mathrm{M}$ & Not clear & cells & [17] \\
\hline Colorimetric & $\begin{array}{c}\text { Diethyldithiocarbamate- } \\
\text { AuNPs }\end{array}$ & $\begin{array}{c}\mathrm{CH}_{3} \mathrm{Hg}^{+}: 15 \mathrm{nM} \\
\mathrm{Hg}^{2+}: 10 \mathrm{nM}\end{array}$ & $\begin{array}{c}\mathrm{CH}_{3} \mathrm{Hg}^{+}: 0.03-0.8 \mu \mathrm{M} ; \\
\mathrm{Hg}^{2+}: 0.01-0.1 \mu \mathrm{M}\end{array}$ & EDTA can mask $\mathrm{Hg}^{2+}$ & drinking water & [18] \\
\hline $\begin{array}{l}\text { Fluorescent sensing } \\
\text { by in-situ synthesis }\end{array}$ & carbon dots & $5.9 \mathrm{nM}$ & $23-278 \mathrm{nM}$ & tolerate with 250 -fold $\mathrm{Hg}^{2+}$ & River/sea water ${ }^{a}$ & [30] \\
\hline $\begin{array}{l}\text { Fluorescent sensing } \\
\text { by in-situ synthesis }\end{array}$ & Silver nanocluster & $0.4 \mathrm{nM}$ & $2.0 \mathrm{nM}-12.0 \mu \mathrm{M}$ & tolerate with 50 -fold $\mathrm{Hg}^{2+}$ & Fish sample & [19] \\
\hline chiro-optical & $\begin{array}{c}\text { adenine -small organic } \\
\text { semiconductor and } \\
\text { oligothymidine }\end{array}$ & $\begin{array}{l}\mathrm{CH}_{3} \mathrm{Hg}^{+} / \mathrm{Hg}^{2+}: \\
0.1 \mathrm{nM}\end{array}$ & $1-1000 \mathrm{nM}$ & - & water & [20] \\
\hline $\begin{array}{l}\text { AIE-based } \\
\text { fluorescence }\end{array}$ & $\begin{array}{l}\text { tetraphenylethylene- } \\
\text { monoboronic acid }\end{array}$ & $\begin{array}{c}\mathrm{CH}_{3} \mathrm{Hg}^{+} / \mathrm{Hg}^{2+}: \\
0.12 \mathrm{ppm}\end{array}$ & $0.6-30 \mathrm{ppm}$ & - & Fish muscle & [31] \\
\hline Colorimetric & $\begin{array}{l}\text { DNA-Templated Ag-Au } \\
\text { nanoparticles synthesis }\end{array}$ & $0.5 \mu \mathrm{M}$ & $0-200 \mu \mathrm{M}$ & tolerate with 50 -fold $\mathrm{Hg}^{2+}$ & Fish muscle & [21] \\
\hline Colorimetric & DNA-AuNPs & $5 \mathrm{nM}$ & $20-500 \mathrm{nM}$ & tolerate with 1-fold $\mathrm{Hg}^{2+}$ & Lake water & This work \\
\hline
\end{tabular}


Table 3. Detection of $\mathrm{CH}_{3} \mathrm{Hg}^{+}$in real water samples $(\mathrm{n}=3)$.

\begin{tabular}{cccc}
\hline Water Sample & Added (nM) & Mean Found (nM) & Mean Recovery (\%) \\
\hline 1 & 20 & $19.1 \pm 0.9$ & $95.5 \%$ \\
2 & 50 & $46.8 \pm 2.3$ & $93.6 \%$ \\
3 & 100 & $102.1 \pm 3.7$ & $102.1 \%$ \\
\hline
\end{tabular}

\section{Conclusions}

In summary, we developed a highly sensitive and selective colorimetric method for the detection of $\mathrm{CH}_{3} \mathrm{Hg}^{+}$, which was based on the surface deposition of $\mathrm{Hg}$ enhancing the catalytic activity of AuNPs. The limit of detection was $5.0 \mathrm{nM}$ with a linear range of $10-200 \mathrm{nM}$. This colorimetric method has potential in the detection of $\mathrm{CH}_{3} \mathrm{Hg}^{+}$in environmental samples since it also demonstrated other advantages of being simple, rapid and cost-effective. However, this method needs to be further improved with respect to its selectivity to $\mathrm{Hg}^{2+}$. This probably can be further improved through adopting magnetic core gold shell nanocomposites due to their more convenient separation and enrichment capability.

Supplementary Materials: The following are available online at http:/ / www.mdpi.com/1424-8220/18/8/2679/ s1, Figure S1. Chromogenic reaction of TMB; Figure S2. UV-vis spectra of citrate-stabilized AuNPs + TMB- $\mathrm{H}_{2} \mathrm{O}_{2}$ reaction solution.

Author Contributions: Z.-J.X. mainly run the experiments, X.-Y.B. provided some reagents and participated in the draft writing, and C.-F.P. conceived and designed the experiments.

Funding: This research was funded by the Open Project Program of State Key Laboratory of Dairy Biotechnology, Bright Dairy \& Food Co. Ltd. (SKLDB2017-00) and the Science and Technology Innovation Committee of Shenzhen (CXZZ20140419150802007), the National Natural Science Foundation of China (31371767).

Conflicts of Interest: The authors declare no conflict of interest.

\section{References}

1. Lin, Y.-H.; Tseng, W.-L. Ultrasensitive Sensing of $\mathrm{Hg}^{2+}$ and $\mathrm{CH}_{3} \mathrm{Hg}^{+}$Based on the Fluorescence Quenching of Lysozyme Type VI-Stabilized Gold Nanoclusters. Anal. Chem. 2010, 82, 9194-9200. [CrossRef] [PubMed]

2. Liu, D.B.; Qu, W.S.; Chen, W.W.; Zhang, W.; Wang, Z.; Jiang, X.Y. Highly Sensitive, Colorimetric Detection of Mercury(II) in Aqueous Media by Quaternary Ammonium Group-Capped Gold Nanoparticles at Room Temperature. Anal. Chem. 2010, 82, 9606-9610. [CrossRef] [PubMed]

3. Myers, G.J.; Marsh, D.O.; Davidson, P.W.; Cox, C.; Shamlaye, C.F.; Tanner, M.; Choi, A.; Cernichiari, E.; Choisy, O.; Clarkson, T.W. Main neurodevelopmental study of Seychellois children following in utero exposure to methylmercury from a maternal fish diet: Outcome at six months. Neurotoxicology 1995, 16, 653-664. [PubMed]

4. Hight, S.C.; Cheng, J. Determination of methylmercury and estimation of total mercury in seafood using high performance liquid chromatography (HPLC) and inductively coupled plasma-mass spectrometry (ICP-MS): Method development and validation. Anal. Chim. Acta 2006, 567, 160-172. [CrossRef]

5. Vallant, B.; Kadnar, R.; Goessler, W. Development of a new HPLC method for the determination of inorganic and methylmercury in biological samples with ICP-MS detection. J. Anal. At. Spectrom. 2007, 22, 322-325. [CrossRef]

6. Gao, Y.; Galan, S.D.; Brauwere, A.D.; Baeyens, W.; Leermakers, M. Mercury speciation in hair by headspace injection-gas chromatography-atomic fluorescence spectrometry (methylmercury) and combustion-atomic absorption spectrometry (total Hg). Talanta 2010, 82, 1919-1923. [CrossRef] [PubMed]

7. Priyadarshini, E.; Pradhan, N. Gold nanoparticles as efficient sensors in colorimetric detection of toxic metal ions: A review. Sens. Actuators B Chem. 2017, 238, 888-902. [CrossRef]

8. Mao, S.; Chang, J.; Zhou, G.; Chen, J. Nanomaterial-enabled Rapid Detection of Water Contaminants. Small 2015, 11, 5336-5359. [CrossRef] [PubMed]

9. Mehta, J.; Bhardwaj, S.K.; Bhardwaj, N.; Paul, A.K.; Kumar, P.; Kim, K.H.; Deep, A. Progress in the biosensing techniques for trace-level heavy metals. Biotechnol. Adv. 2016, 34, 47-60. [CrossRef] [PubMed] 
10. Chen, L.; Li, J.; Chen, L.X. Colorimetric Detection of Mercury Species Based on Functionalized Gold Nanoparticles. ACS Appl. Mater. Interfaces 2014, 6, 15897-15904. [CrossRef] [PubMed]

11. Sener, G.; Uzun, L.; Denizli, A. Lysine-Promoted Colorimetric Response of Gold Nanoparticles: A Simple Assay for Ultrasensitive Mercury(II) Detection. Anal. Chem. 2014, 86, 514-520. [CrossRef] [PubMed]

12. Jin, L.H.; Han, C.S. Eco-friendly colorimetric detection of mercury(II) ions using label-free anisotropic nanogolds in ascorbic acid solution. Sens. Actuators B Chem. 2014, 195, 239-245. [CrossRef]

13. Liu, H.; Ma, L.; Ma, C.; Du, J.; Wang, M.; Wang, K. Quencher-Free Fluorescence Method for the Detection of Mercury(II) Based on Polymerase-Aided Photoinduced Electron Transfer Strategy. Sensors 2016, 16, 1945. [CrossRef] [PubMed]

14. Xiao, W.; Xiao, M.; Fu, Q.; Yu, S.; Shen, H.; Bian, H.; Tang, Y. A Portable Smart-Phone Readout Device for the Detection of Mercury Contamination Based on an Aptamer-Assay Nanosensor. Sensors 2016, $16,1871$. [CrossRef] [PubMed]

15. Kamaruddin, N.; Bakar, A.A.; Mobarak, N.; Zan, M.S.; Arsad, N. Binding Affinity of a Highly Sensitive $\mathrm{Au} / \mathrm{Ag} / \mathrm{Au} / \mathrm{Chitosan}-G r a p h e n e$ Oxide Sensor Based on Direct Detection of $\mathrm{Pb}^{2+}$ and $\mathrm{Hg}^{2+}$ Ions. Sensors 2017, 17, 2277. [CrossRef] [PubMed]

16. Wang, G.L.; Zhu, X.Y.; Jiao, H.J.; Dong, Y.M.; Li, Z.J. Ultrasensitive and dual functional colorimetric sensors for mercury (II) ions and hydrogen peroxide based on catalytic reduction property of silver nanoparticles. Biosens. Bioelectron. 2012, 31, 337-342. [CrossRef] [PubMed]

17. Liu, Y.; Chen, M.; Cao, T.; Sun, Y.; Li, C.; Liu, Q.; Yang, T.; Yao, L.; Feng, W.; Li, F. A cyanine-modified nanosystem for in vivo upconversion luminescence bioimaging of methylmercury. J. Am. Chem. Soc. 2013, 135, 9869-9876. [CrossRef] [PubMed]

18. Chen, L.; Li, J.; Chen, L. Colorimetric detection of mercury species based on functionalized gold nanoparticles. ACS Appl. Mater. Interfaces 2014, 6, 15897-15904. [CrossRef] [PubMed]

19. Deng, L.; Li, Y.; Yan, X.; Xiao, J.; Ma, C.; Zheng, J.; Liu, S.; Yang, R. Ultrasensitive and highly selective detection of bioaccumulation of methyl-mercury in fish samples via $\mathrm{Ag}^{0} / \mathrm{Hg}^{0}$ amalgamation. Anal. Chem. 2015, 87, 2452-2458. [CrossRef] [PubMed]

20. Pandeeswar, M.; Senanayak, S.P.; Govindaraju, T. Nanoarchitectonics of Small Molecule and DNA for Ultrasensitive Detection of Mercury. ACS Appl. Mater. Interfaces 2016, 8, 30362-30371. [CrossRef] [PubMed]

21. Chen, Z.; Wang, X.; Cheng, X.; Yang, W.; Wu, Y.; Fu, F. Specifically and Visually Detect Methyl-Mercury and Ethyl-Mercury in Fish Sample Based on DNA-Templated Alloy Ag-Au Nanoparticles. Anal. Chem. 2018, 90, 5489-5495. [CrossRef] [PubMed]

22. Long, Y.J.; Li, Y.F.; Liu, Y.; Zheng, J.J.; Tang, J.; Huang, C.Z. Visual observation of the mercury-stimulated peroxidase mimetic activity of gold nanoparticles. Chem. Commun. 2011, 47, 11939-11941. [CrossRef] [PubMed]

23. Yan, L.; Chen, Z.P.; Zhang, Z.Y.; Qu, C.L.; Chen, L.X.; Shen, D.Z. Fluorescent sensing of mercury(II) based on formation of catalytic gold nanoparticles. Analyst 2013, 138, 4280-4283. [CrossRef] [PubMed]

24. Peng, C.-F.; Pan, N.; Xie, Z.-J.; Wu, L.-L. Highly sensitive and selective colorimetric detection of $\mathrm{Hg}^{2+}$ based on the separation of $\mathrm{Hg}^{2+}$ and formation of catalytic DNA-gold nanoparticles. Anal. Methods 2016, 8, 1021-1025. [CrossRef]

25. Wu, L.-L.; Wang, L.-Y.; Xie, Z.-J.; Xue, F.; Peng, C.-F. Colorimetric detection of $\mathrm{Hg}^{2+}$ based on inhibiting the peroxidase-like activity of DNA-Ag/Pt nanoclusters. RSC Adv. 2016, 6, 75384-75389. [CrossRef]

26. Wang, C.I.; Huang, C.C.; Lin, Y.W.; Chen, W.T.; Chang, H.T. Catalytic gold nanoparticles for fluorescent detection of mercury(II) and lead(II) ions. Anal. Chim. Acta 2012, 745, 124-130. [CrossRef] [PubMed]

27. Kenduzler, E.; Ates, M.; Arslan, Z.; McHenry, M.; Tchounwou, P.B. Determination of mercury in fish otoliths by cold vapor generation inductively coupled plasma mass spectrometry (CVG-ICP-MS). Talanta 2012, 93, 404-410. [CrossRef] [PubMed]

28. Monteiro, A.d.C.P.; de Andrade, L.S.N.; Luna, A.S.; de Campos, R.C. Sequential quantification of methyl mercury in biological materials by selective reduction in the presence of mercury(II), using two gas-liquid separators. Spectrochim. Acta Part B At. Spectrosc. 2002, 57, 2103-2112. [CrossRef]

29. Yin, J.; Cao, H.; Lu, Y. Self-assembly into magnetic $\mathrm{Co}_{3} \mathrm{O}_{4}$ complex nanostructures as peroxidase. J. Mater. Chem. 2012, 22, 527-534. [CrossRef] 
30. Costas-Mora, I.; Romero, V.; Lavilla, I.; Bendicho, C. In situ building of a nanoprobe based on fluorescent carbon dots for methylmercury detection. Anal. Chem. 2014, 86, 4536-4543. [CrossRef] [PubMed]

31. Chatterjee, A.; Banerjee, M.; Khandare, D.G.; Gawas, R.U.; Mascarenhas, S.C.; Ganguly, A.; Gupta, R.; Joshi, H. Aggregation-Induced Emission-Based Chemodosimeter Approach for Selective Sensing and Imaging of $\mathrm{Hg}(\mathrm{II})$ and Methylmercury Species. Anal. Chem. 2017, 89, 12698-12704. [CrossRef] [PubMed] 